\title{
PENGARUH MEKANISME CORPORATE GOVERNANCE TERHADAP KINERJA KEUANGAN BADAN USAHA
}

Filia Puspitasari dan Endang Ernawati

Universitas Surabaya, email: endangernawati@yahoo.com

\begin{abstract}
Nowdays, most researches in corporate governance field are conducted by researchers based on rising of many firms to become public corporation. According to this situation, they have to separate their functions on ownership and control of the firm. As result, it will arise agency conflict between owners and managers. The corporation enable solve the problem by apply the corporate governance mechanism optimally. This research is a replication research is conducted by Sanda et al (2005). It's explained the specific study about the impact of corporate governance mechanism include managerial ownership, board size, outside directors, ownership concentration, and debt toward financial performance that measured by ROA, ROE, PER, and TOBINS' $Q$. The samples of this research are all corporations which listed at Bursa Efek Indonesia (BEI) by all sectors that delivered financial statement on time by regulation. The period of time in this research determined on 2005-2007. The model is extended by quadratic of managerial ownership, quadratic of board size, quadratic of ownership concentration, CEO foreign and firm size as control variables, and sectoral dummy. The result of this research explained that corporate governance mechanism simultaneously influence to ROA and ROE significantly. On partially, ROA is influenced by CEO foreign, debt, and firm size significantly. And ROE is inluenced by CEO foreign, firm size, and sector of basic industry significantly.
\end{abstract}

Keywords: corporate governance, financial performance.

\section{PENDAHULUAN}

Sejak 1999 (pasca krisis 1998), jumlah badan usaha yang mendaftarkan diri ke Bursa Efek Indonesia (BEI) menunjukkan peningkatan yang cukup signifikan. Hal ini berarti bahwa semakin banyak badan usaha yang harus melakukan pemisahan fungsi antara fungsi kepemilikan dan pengelolaan. Fungsi kepemilikan berada di tangan pemegang saham atau pemilik, sedangkan fungsi pengelolaan dilaksanakan oleh para manajer badan usaha. 
Teori keagenan (agency theory) mengemukakan, jika antara pihak principal (pemilik) dan agent (manajer) memiliki kepentingan yang berbeda, maka akan muncul konflik yang dinamakan agency conflict (Jensen dan Meckling, 1976). Pemisahan kepemilikan akan menimbulkan konflik dalam pengendalian dan pelaksanaan pengelolaan badan usaha, disebabkan para manajer tidak bertindak sesuai keinginan pemilik (pemegang saham).

Benhart dan Rosenstein (1998) menyatakan suatu mekanisme yang dapat mengatasi masalah keagenan tersebut, yaitu mekanisme corporate governance. Dalam mekanisme corporate governance, terdapat mekanisme internal, seperti struktur dan kepemilikan dewan komisaris, serta mekanisme eksternal, seperti pasar modal. Corporate governance berkaitan erat dengan mekanisme dalam suatu badan usaha di mana berbagai pihak yang berkepentingan terhadap badan usaha tersebut dapat memastikan bahwa pihak manajer dan pihak internal badan usaha lainnya dapat memenuhi kepentingan stakeholder.

Pemerintah Indonesia dan IMF (International Monetary Fund) memperkenalkan konsep Good Corporate Governance (GCG) sebagai tata kelola badan usaha yang sehat (Sulistyanto dan Warastuti, 2003). Dengan adanya Good Corporate Governance diharapkan profesionalisme pihak manajer dapat ditingkatkan, sehingga kesejahteraan pemegang saham meningkat dan kepentingan stakeholder lain tidak diabaikan. Lima (5) komponen utama yang digunakan untuk menilai penerapan GCG (Swa no.26/XXII/11, 20 Desember 2006, halaman 62) adalah transparansi, pengungkapan (disclosure), kemandirian, akuntabilitas, dan keadilan.

Corporate Governance Perception Index (CGPI) adalah riset dan pemeringkatan penerapan GCG di badan usaha publik yang tercatat di BEI. CGPI dilakukan oleh IICG (The Indonesian Institute for Corporate Governance). Pelaksanaan CGPI dilandasi oleh pemikiran tentang pentingnya mengetahui sejauh mana badan usaha publik telah menerapkan GCG. CGPI dimulai pada 2001. Hasil riset dalam pemeringkatan yang telah dilakukan menunjukkan adanya proses pendekatan, penjabaran, dan penyempurnaan penerapan prinsip-prinsip GCG secara berkelanjutan, sehingga dapat diungkap permasalahan yang sering muncul dan konsistensi kepatuhan terhadap regulasi yang ada. Dalam pelaksanaan CGPI, IICG menjalin kerja sama dengan SWA, yang dikenal sebagai salah satu majalah bisnis unggul di Indonesia. Tabel 1 berikut ini menunjukkan jumlah peserta CGPI periode 2002-2007.

Tabel 1

Jumlah Badan Usaha Peserta CGPI

\begin{tabular}{|c|c|c|c|c|c|c|}
\hline Badan Usaha & $\mathbf{2 0 0 2}$ & $\mathbf{2 0 0 3}$ & $\mathbf{2 0 0 4}$ & $\mathbf{2 0 0 5}$ & $\mathbf{2 0 0 6}$ & $\mathbf{2 0 0 7}$ \\
\hline Peserta CGPI & 33 & 31 & 22 & 22 & 22 & 23 \\
\hline
\end{tabular}


Jurnal Manajemen Teori dan Terapan | Tahun 3, No. 2, Agustus 2010 | Filia Puspitasari dan Endang Ermawati

\begin{tabular}{|l|c|c|c|c|c|c|} 
& $(11,1 \%)$ & $(10,2 \%)$ & $(7,1 \%)$ & $(7,0 \%)$ & $(6,9 \%)$ & $(6,3 \%)$ \\
\hline Nonpeserta CGPI & 296 & 302 & 309 & 314 & 317 & 364 \\
\hline
\end{tabular}

Sumber: www.swa.co.id

Dari Tabel 1, dapat dilihat bahwa CGPI hanya diikuti oleh sebagian kecil badan usaha, dibandingkan dengan jumlah badan usaha yang terdaftar di BEl. Oleh karena itu, dalam penelitian ini, tidak digunakan obyek badan usaha-badan usaha berdasarkan data CGPI. Hal ini dikarenakan badan usaha yang tidak mengikuti CGPI belum tentu tidak menerapkan corporate governance.

Dengan menerapkan GCG, maka konflik keagenan menjadi berkurang, sehingga pihak manajer dapat meningkatkan kemakmuran pemilik (pemegang saham). Dengan kata lain, corporate governance merupakan suatu sistem yang mengatur dan mengendalikan badan usaha yang diharapkan dapat meningkatkan kesejahteraan para pemegang saham dan stakeholders lainnya. Siallagan dan Machfoedz (2006) mengemukakan bahwa corporate governance yang efektif dalam jangka panjang dapat meningkatkan kinerja badan usaha dan menguntungkan pemegang saham.

Corporate governance merupakan topik yang menarik untuk dibahas. Oleh karena itu, hingga saat ini semakin banyak penelitian mengenai corporate governance, terutama berhubungan dengan kinerja keuangan badan usaha khususnya kinerja jangka panjang. Beberapa penelitian tentang corporate governance yang telah dilakukan sebelumnya. Sanda et al. (2005) meneliti pengaruh mekanisme corporate governance terhadap kinerja keuangan badan usaha di Nigeria, Lefort dan Walker (2005) meneliti pengaruh corporate governance dalam penilaian pasar badan usaha serta kebijakan dividen di Chili, Javed dan lqbal (2007) meneliti hubungan indikator-indikator corporate governance terhadap nilai badan usaha, yang ditunjukkan dengan Tobin's Q, dan Nur (2007) meneliti pengaruh praktik corporate governance terhadap kesulitan keuangan badan usaha.

Penelitian ini merupakan replikasi dari penelitian yang dilakukan oleh Sanda et al. (2005) berjudul "Corporate Governance Mechanisms and Firm Financial Performance in Nigeria". Sanda et al. (2005) meneliti pengaruh mekanisme corporate governance terhadap kinerja keuangan badan usaha. Mekanisme corporate governance terdiri dari dimensi-dimensi corporate governance, yaitu kepemilikan manajerial, jumlah dewan komisaris, proporsi komisaris independen, konsentrasi kepemilikan, dan proporsi utang (leverage). Dalam penelitian ditambahkan variabel dummy status CEO (untuk menguji efek nonlinear board independence) dan variabel dummy CEO ekspatriat atau lokal, yang merujuk pada penelitian Laing dan Weir (1999) serta Estrin et al. (2001). Sampel yang diteliti meliputi badan 
usaha yang terdaftar di Nigerian Stock Exchange periode 1996 sampai dengan 1999 dan memiliki data mengenai komisaris, lembar saham yang dimiliki oleh pihak manajer dan jumlah lembar saham yang beredar, nilai aset total, nilai modal saham dan keuntungan pertahun (profit after tax). Variabel dependen yang digunakan adalah PER, ROA, ROE, Modified Tobin's Q. Variabel independen yang digunakan adalah kepemilikan manajerial (INDSHARE), ukuran dewan komisaris (BOARDSIZE), komisaris independen (OUTSIDE), konsentrasi kepemilikan (CONCENT), debt, firm size (FIRMSIZE), CEO status, CEO foreign, dan sectoral dummmies $\left(\mathrm{SD}_{\mathrm{i}}\right)$.

Penelitian ini menggunakan obyek semua badan usaha yang terdaftar di BEl periode 2005 sampai dengan 2007, tidak terbatas pada sektor tertentu. Ruang lingkup obyek penelitian ini dibatasi hanya pada badan usaha yang secara konsisten tepat waktu menyerahkan laporan keuangan pada BEl, sesuai dengan salah satu unsur corporate governance, yaitu akuntabilitas. Penelitian ini bertujuan mengetahui pengaruh mekanisme corporate governance terhadap kinerja keuangan badan usaha yang terdaftar di BEl periode 2005-2007. Prioritas penelitian adalah mekanisme internal corporate governance. Oleh karena itu, model penelitian dikembangkan berdasarkan mekanisme internal corporate governance. Selain itu, penelitian ini juga bertujuan mengetahui besarnya pengaruh serta arah (positif/ negatif) pengaruh tersebut terhadap kinerja keuangan badan usaha. Dengan demikian, dapat diketahui dimensi corporate governance yang paling berpengaruh dalam rangka meningkatkan kinerja badan usaha.

Berdasarkan latar belakang yang telah dikemukakan, rumusan masalah dalam penelitian ini, yaitu: apakah mekanisme corporate governance baik internal maupun eksternal berpengaruh terhadap kinerja keuangan badan usaha-badan usaha yang terdaftar di Bursa Efek Indonesia selama periode 2005-2007?

\section{LANDASAN TEORI DAN PENGEMBANGAN HIPOTESIS}

Corporate Governance

Istilah corporate governance secara luas telah dikenal dalam dunia usaha. OECD dalam Siswanto dan Aldridge (2005:2) mendefinisikan corporate governance sebagai suatu sistem pengendalian dan pengawasan pada suatu badan usaha yang memiliki tujuan untuk mencapai kinerja badan usaha semaksimal mungkin tanpa merugikan stakeholdernya. Setiap badan usaha memiliki pihak-pihak yang berkepentingan terhadap badan usaha tersebut, antara lain pihak manajer, pemegang saham (yang diwakili oleh dewan komisaris), 
karyawan, serta stakeholder lainnya, seperti masyarakat, konsumen, pemerintah, pers, dan lain-lain.

Corporate governance sebagai variabel independen diukur dengan menggunakan mekanisme corporate governance. Mekanisme corporate governance adalah syarat-syarat pelaksanaan sistem dalam suatu badan usaha di mana berbagai pihak yang berkepentingan terhadap badan usaha tersebut dapat memastikan bahwa pihak manajer dan pihak internal badan usaha lainnya dapat memenuhi kepentingan stakeholder (Sanda et al., 2005). Mekanisme corporate governance yang baik akan menghasilkan kinerja badan usaha yang lebih baik. Mekanisme corporate governance terdiri dari dimensi-dimensi corporate governance. Mekanisme tersebut terbagi menjadi mekanisme internal dan mekanisme eksternal (Sanda et al., 2005). Yang termasuk dalam mekanisme internal adalah kepemilikan manajerial, ukuran dewan komisaris, komisaris independen, dan konsentrasi kepemilikan. Utang (leverage) merupakan mekanisme eksternal corporate governance. Selain menggunakan mekanisme corporate governance, Sanda et al. juga memasukkan variabel kontrol dalam penelitiannya, yaitu CEO ekspatriat, ukuran badan usaha, dan sektor.

Kay (1992) mengatakan bahwa kepemilikan manajerial merupakan kepemilikan sejumlah saham badan usaha oleh pihak eksekutif sehingga membuat eksekutif yang melakukan akuisisi saham badan usaha memiliki kinerja lebih baik dibandingkan eksekutif yang tidak memiliki saham badan usaha. Davies et al. (2002) menyatakan bahwa: "Managerial ownership is equity ownership by inside company managers in providing incentives to maximize the value of their company". Kepemilikan manajerial diukur dengan perbandingan jumlah saham yang dimiliki oleh pihak manajer terhadap jumlah saham beredar (Sanda et al. 2005).

Ukuran dewan komisaris merupakan jumlah yang tepat agar dewan komisaris dapat bekerja secara efektif dan menjalankan corporate governance dengan bertanggung jawab kepada pemegang saham (Ruvisky, 2005). Jumlah yang tepat berarti jumlah yang dianggap proporsional untuk mewakili pemegang saham. Jadi, ukuran dewan komisaris merupakan jumlah yang dianggap proporsional untuk mewakili pemegang saham badan usaha agar dewan komisaris dapat bekerja secara efektif dan menjalankan corporate governance dengan bertanggung jawab kepada pemegang saham.

Dewan komisaris independen menunjukkan keberadaan wakil dari pemegang saham secara independen dan juga mewakili kepentingan investor. Peraturan Bank Indonesia no.8/ 4/ PBI/ 2006 pasal 4 mengenai komisaris independen: "Komisaris Independen adalah 
anggota dewan komisaris yang tidak memiliki hubungan keuangan, kepengurusan, kepemilikan saham dan/ atau hubungan keluarga dengan anggota dewan komisaris lainnya, direksi dan/ atau pemegang saham pengendali atau hubungan lain yang dapat mempengaruhi kemampuannya untuk bertindak independen." Komisaris independen diukur dengan menggunakan proporsi komisaris independen yang duduk pada jajaran dewan komisaris (Sanda et al., 2005). Sanda et al. (2005) menyatakan bahwa konsentrasi kepemilikan merupakan proporsi lembar saham badan usaha yang dimiliki oleh pemegang saham terbesar. Menurut Mitton (2002): "Ownership concentration is cumulative stock ownership of shareholder who owns at least 5 percent in the firm." Jadi, konsentrasi kepemilikan merupakan proporsi lembar saham badan usaha yang dimiliki oleh pemegang saham terbesar dengan syarat kepemilikan paling sedikit $5 \%$ dari jumlah lembar saham yang beredar. Untuk mengukur konsentrasi kepemilikan, digunakan formula jumlah lembar saham badan usaha yang dimiliki oleh pemegang saham terbesar dibandingkan dengan jumlah lembar saham yang beredar (Sanda et al., 2005).

Utang merupakan sarana pembiayaan yang mempunyai klaim kontraktual atas arus kas dan aset badan usaha, menciptakan penghematan pajak, mempunyai umur tertentu, dan memiliki klaim pertama atas arus kas selama periode operasi maupun kebangkrutan (Damodaran, 2001:483). Menurut Jensen dan Meckling (1976), kebijakan utang dapat berperan sebagai mekanisme penjamin bagi pihak manajer untuk menunjukkan niat baiknya kepada pemegang saham. Hal ini dikarenakan penggunaan utang menunjukkan bahwa pihak manajer bersedia untuk menerima risiko kehilangan kendali atas badan usahanya jika gagal bekerja secara efektif (Smart, Megginson, dan Gitman, 2004:455). Alat ukur utang yang digunakan dalam penelitian ini merujuk pada Sanda et al. (2005), yaitu proporsi utang terhadap ekuitas (share capital).

Peran pihak manajer dalam keberhasilan badan usaha sangat penting. Pengalaman bekerja dan jiwa kewirausahaan mempengaruhi kinerja suatu badan usaha. Sanda et al. (2005) membandingkan kinerja antara CEO asing (ekspatriat) dengan CEO lokal (berasal dari Nigeria). Perbedaan negara asal tersebut menyebabkan perbedaan pengetahuan dan keahlian yang dimiliki.

Ukuran badan usaha dapat dilihat dari aset total badan usaha pada akhir periode fiskal. Badan usaha yang memiliki aset besar dapat dengan mudah mengakses pasar modal. Dengan adanya kemudahan untuk mengakses pasar modal, berarti badan usaha tersebut memiliki fleksibilitas dan kemampuan mendapatkan dana. Megginson (1997:375) menyatakan ukuran badan usaha yang besar cenderung membagikan dividen untuk 
menghindari konflik keagenan antara pihak manajer dengan pemilik. Dalam penelitiannya, Sanda et al. (2005) menggunakan natural log aset total sebagai variabel kontrol. Hal ini dimaksudkan menghindari bias karena perbedaan ukuran badan usaha.

Sanda et al. (2005) menyatakan bahwa setiap sektor memiliki risiko bisnis yang berbeda. Pengaruh masing-masing sektor terhadap efektivitas corporate governance berbeda. Oleh karena itu, dalam penelitian dilakukan pengukuran terhadap masing-masing sektor terhadap efektivitas corporate governance.

Kinerja Kevangan

Kinerja keuangan sebagai variabel dependen diukur dengan menggunakan rasio profitabilitas dan rasio pasar. Rasio profitabilitas yang digunakan adalah ROA dan ROE, sedangkan PER dan Tobin'Q mewakili rasio pasar. ROA (Return on Asset) merupakan sebuah pengukuran mengenai efektivitas aset badan usaha yang digunakan untuk menghasilkan laba (Gitman, 2003:65). Efektivitas terkait dengan kemampuan pihak manajer dalam mengelola sumber daya badan usaha. Jadi, ROA (Return on Asset) merupakan pengukuran mengenai kemampuan pihak manajer badan usaha dalam mengelola aset yang digunakan untuk menghasilkan laba. ROA dapat diperoleh dengan cara membandingkan net profit terhadap total assets. Sedangkan ROE (Return on Equity) adalah rasio laba bersih sesudah pajak terhadap modal sendiri untuk mengukur tingkat hasil investasi pemegang saham (Weston dan Copeland, 1987:233). Nilai ROE yang semakin tinggi mengindikasikan tingkat hasil yang lebih baik kepada pemegang saham atas investasinya. Selain itu, nilai ROE yang tinggi menunjukkan penerimaan badan usaha atas investasi yang sangat baik dan manajemen biaya yang efektif (Sabardi, 1995:116). ROE dapat dihitung dengan membandingkan net profit terhadap equity value.

PER (Price per Earning Ratio) merupakan sebuah rasio antara share price dibandingkan earning per share (Moin, Abdul, 2003:175). Sementara laba perlembar saham adalah net income dibagi number shares outstanding. Sedangkan Tobin's $Q$ is defined as the ratio of market value of debt and equity of the firm to the replacement cost of the firm (Nor et al., 1999). Dari pernyataan tersebut, dapat dijelaskan bahwa Tobins' $Q$ merupakan rasio nilai pasar utang dan ekuitas badan usaha terhadap biaya penggantian badan usaha tersebut. Menurut Sanda et al. (2005) merujuk pada penelitian Demirguc-Kunt (1992), dalam perhitungan Tobin's $Q$, digunakan book value of total assets sebagai proksi replacement cost karena informasi replacement cost sulit diakses. Selain itu, pendekatan kapitalisasi pasar pada akhir tahun digunakan untuk modifikasi Tobins' $Q$. Tobins' $Q$ dapat diperoleh dari year 
end market capitalization dibagi book value of total assets. Sedangkan year end market capitalization diperoleh dengan mengalikan number shares outstanding dengan share price.

Pengaruh Kepemilikan Manajerial terhadap Kinerja Keuangan

Gudono (2000) meneliti mengenai dampak kepemilikan saham oleh pihak manajer terhadap prestasi badan usaha dibandingkan dengan kontrak kompensasi. Hasil penelitian menunjukkan kepemilikan saham oleh pihak manajer memiliki pengaruh signifikan positif terhadap kinerja keuangan (kombinasi dari ROA, ROE, PER). Pihak manajer yang memiliki saham badan usaha cenderung melakukan strategi untuk meningkatkan kinerja badan usaha dalam jangka panjang. Contoh strategi yang diambil adalah integrasi terhadap badan usaha lain dengan mempertimbangkan peningkatan penjualan jangka panjang.

Mehran (1994) mengungkapkan hasil penelitian senada dengan menyatakan bahwa terdapat pengaruh signifikan positif antara persentase saham yang dimiliki pihak manajer dengan kinerja keuangan badan usaha. Insentif berupa saham yang diberikan kepada pihak manajer memacu mereka untuk bekerja lebih keras dan cerdas dalam meningkatkan nilai badan usaha, yang juga merupakan milik pihak manajer. Sanda et al. (2005) meneliti adanya efek nonlinear kepemilikan manajerial terhadap kinerja keuangan badan usaha. Pada titik tertentu, hubungan tersebut menjadi berlawanan dengan kondisi awal. Oleh karena itu, digunakan persamaan kuadrat kepemilikan manajemen untuk meneliti efek nonlinearnya. Short dan Keasey (1999) dalam Nur (2007) menyatakan hal senada dengan Sanda et al. (2005), yaitu terdapat hubungan nonlinear antara kepemilikan manajerial dengan nilai badan usaha di Inggris. Hubungan linear tersebut juga ditunjukkan terhadap kinerja badan usaha.

Pengaruh Ukuran Dewan Komisaris terhadap Kinerja Keuangan

Yang et al. (2006) meneliti pengaruh jumlah dewan komisaris terhadap kinerja keuangan badan usaha. Hasil penelitian tersebut adalah ukuran dewan komisaris berpengaruh negatif terhadap kinerja badan usaha. Hal ini mendukung hasil penelitian Sanda et al. (2005). Jumlah dewan komisaris yang terlalu besar menyebabkan lambatnya proses pengambilan keputusan. Hal ini disebabkan keputusan yang diambil harus didiskusikan terlebih dahulu dan diambil kesepakatan dari semua dewan komisaris. Selain itu, keputusan tidak bersifat dinamis, karena untuk mengubah suatu keputusan yang telah diambil, membutuhkan waktu lebih lama untuk berunding dan memperoleh kesepakatan bersama. Dengan demikian, 
efektivitas pengambilan keputusan menjadi berkurang dan mengakibatkan penurunan kinerja badan usaha. Keputusan yang dimaksud adalah keputusan non-managerial. Keputusan yang menjadi wewenang dewan komisaris adalah keputusan mengenai hal-hal yang ditetapkan dalam anggaran dasar atau peraturan perundangan. Pengambilan keputusan tersebut dilakukan dalam fungsi dewan komisaris sebagai pengawas, sehingga keputusan yang menyangkut kegiatan operasional tetap menjadi tanggung jawab pihak manajer. Kewenangan yang ada pada dewan komisaris tetap dilakukan dalam fungsinya sebagai pengawas dan penasehat. Contoh keputusan yang diambil oleh dewan komisaris adalah mengenakan sanksi kepada anggota manajemen, membentuk komite guna kelancaran kinerja badan usaha.

Sanda et al. (2005) meneliti adanya efek nonlinear jumlah dewan komisaris terhadap kinerja keuangan badan usaha. Pada titik tertentu, hubungan tersebut menjadi berlawanan dengan kondisi awal. Oleh karena itu, digunakan persamaan kuadrat jumlah dewan komisaris untuk meneliti efek nonlinearnya.

Pengaruh Komisaris Independen terhadap Kinerja Keuangan

Mehran (1994) mengemukakan bahwa proporsi komisaris independen berpengaruh positif terhadap kinerja badan usaha (terutama terhadap ROA dan Tobins' $Q$ ). There is a growing body of evidence that outside directors are more independent of top management and thus better represent the interest of shareholders than do inside directors. Dengan adanya komisaris independen, maka kepentingan pemegang saham, baik mayoritas dan minoritas tidak diabaikan, karena komisaris independen lebih bersikap netral terhadap keputusan yang dibuat oleh pihak manajer. Rosenstein dan Wyatt (1990) dalam Mehran (1994) menyatakan bahwa penunjukkan komisaris independen berpengaruh positif terhadap harga saham secara rata-rata. Dengan kata lain akan meningkatkan nilai PER (Price per Earning Ratio). Kenaikan harga saham tersebut mengindikasikan kepercayaan investor terhadap komisaris independen, yang dianggap lebih tidak memihak dalam menjalankan fungsinya sebagai wakil pemegang saham.

Fama dan Jensen (1983) dalam Nur (2007) menyatakan bahwa komisaris independen akan lebih efektif dalam memonitor pihak manajer. Pemonitoran oleh komisaris independen atau eksternal dinilai mampu memecahkan masalah keagenan. Selain itu, komisaris independen dapat memberikan kontribusi terhadap nilai badan usaha. Komisaris independen dapat memberikan kontribusi terhadap nilai badan usaha melalui aktivitas evaluasi dan keputusan stratejik. Informasi yang diberikan tersebut diharapkan mampu menjadi panduan bagi pihak 
manajer dalam menjalankan badan usaha. Dengan demikian, potensi mismanagement yang berakibat pada kesulitan keuangan dapat diminimumkan. Berkurangnya mismanagement menyebabkan peningkatan kinerja badan usaha, karena efektivitas dan efisiensi pengelolaan akan tercapai.

Pengaruh Konsentrasi Kepemilikan terhadap Kinerja Keuangan

Chantrataragul (2007) meneliti mengenai konsentrasi kepemilikan dalam hubungannya dengan kinerja keuangan badan usaha di Thailand. Hasil penelitian adalah semakin tinggi konsentrasi kepemilikan, maka akan menghasilkan kinerja keuangan yang lebih baik (terutama dalam hal Tobin's Q). Jika pemonitoran pihak manajer dilakukan oleh pemegang saham yang memiliki kepemilikan saham tersebar (persentase kepemilikan kecil), maka tekanan untuk mengawasi pihak manajer rendah. Sebagai akibatnya, pihak manajer dapat bertindak sesuai dengan kepentingannya sendiri.

Jika kepemilikan saham terkonsentrasi, maka pengawasan terhadap pihak manajer akan lebih ketat. Selain itu, dengan adanya konsentrasi kepemilikan pada tingkat tinggi, maka keragaman kepentingan pemegang saham berkurang, sehingga kemungkinan terbentuknya kerja sama antara pihak manajer dan pemegang saham untuk meningkatkan nilai badan usaha semakin tinggi. Dengan demikian, konsentrasi kepemilikan berpengaruh positif terhadap kinerja keuangan badan usaha. Sanda et al. (2005) melakukan penelitian terhadap adanya efek nonlinear konsentrasi kepemilikan terhadap kinerja keuangan badan usaha. Pada titik tertentu, hubungan tersebut menjadi berlawanan dengan kondisi awal. Oleh karena itu, digunakan persamaan kuadrat konsentrasi kepemilikan untuk meneliti efek nonlinearnya.

Pengaruh Utang terhadap Kinerja Keuangan

Tandelilin dan Wilberforce (2000) meneliti mengenai kepemilikan manajerial, kebijakan dividen dan kebijakan utang dalam hubungannya dengan kinerja keuangan badan usaha. Hasil penelitian menunjukkan bahwa utang berpengaruh negatif terhadap kinerja keuangan badan usaha, terutama dalam hal profitabilitas. Sanda et al. (2005) menyatakan bahwa pengaruh negatif utang terhadap kinerja keuangan badan usaha disebabkan oleh kemungkinan konflik kepentingan antara pihak debtholder (yang biasanya memiliki perwakilan dalam dewan komisaris) dengan pemegang saham. Debtholder menginginkan badan usaha memiliki stabilitas agar dapat membayar utang, sehingga debtholder tidak menghendaki adanya strategi badan usaha yang mengancam kemampuan badan usaha 
untuk membayar utang. Dengan kata lain, debtholder menginginkan badan usaha tidak meningkatkan risiko gagal bayar. Di pihak lain, pemegang saham bertujuan memaksimumkan kemakmurannya, sehingga pemegang saham menginginkan badan usaha melakukan strategi yang dapat menaikkan harga saham. Perbedaan kepentingan antara debtholder dan pemegang saham ini merupakan bentuk lain dari konflik keagenan, selain konflik kepentingan antara pemegang saham dengan pihak manajer badan usaha.

Secara teoritis, konflik keagenan antara pemegang saham dan pihak manajer dapat dikurangi dengan menghadirkan pihak ketiga, yaitu debtholder (Jensen dan Meckling, 1976). Namun, karena kehadiran pihak ketiga tersebut, muncul konflik keagenan dalam bentuk lain. Artinya, keputusan terhadap pendanaan dengan utang memiliki risiko tersendiri.

Utang merupakan mekanisme eksternal corporate governance. Mekanisme eksternal corporate governance ini memiliki pengaruh negatif terhadap kinerja keuangan badan usaha karena memunculkan konflik keagenan yang lain. Jadi, utang berpengaruh negatif terhadap kinerja keuangan badan usaha.

Pengaruh CEO Ekspatriat terhadap Kinerja Keuangan

Hasil penelitian Sanda et al. (2005) mengenai pengaruh CEO ekpatriat dan lokal terhadap kinerja badan usaha adalah badan usaha yang dikelola oleh CEO ekspatriat cenderung menghasilkan kinerja keuangan yang lebih baik daripada badan usaha yang memiliki CEO lokal saja. CEO ekspatriat berpengaruh signifikan positif terhadap ROA dan ROE. CEO ekspatriat, terutama yang berasal dari negara yang lebih maju dari Nigeria, cenderung membawa teknik manajemen yang lebih modern dan memiliki pengetahuan dan keahlian internasional yang lebih baik. Jika CEO ekspatriat yang berasal dari negara yang memiliki pengetahuan dan teknologi lebih baik, maka badan usaha akan mengharapkan terjadinya technology spillover atau knowledge spillover. Dengan adanya transfer pengetahuan dan teknologi dari negara yang lebih maju melalui CEO ekspatriat, maka efektivitas dan efisiensi pengelolaan badan usaha dapat ditingkatkan. Hal ini secara langsung berdampak pada kinerja keuangan badan usaha.

Hipotesis

Berdasarkan fakta, permasalahan, dan telaah teoritis yang telah dirumuskan sebelumya, maka dapat dibuat dugaan sementara (hipotesis) yang harus diuji kebenarannya. Hipotesis yang telah dirumuskan adalah sebagai berikut: "Diduga mekanisme corporate governance 
baik internal maupun eksternal berpengaruh terhadap kinerja keuangan badan usahabadan usaha yang terdaftar di Bursa Efek Indonesia selama periode 2005-2007."

\section{METODE PENELITIAN}

Populasi penelitian ini adalah semua badan usaha yang terdaftar di BEl badan usaha yang konsisten mempublikasikan laporan keuangan yang telah diaudit atau menyerahkan laporan keuangan yang telah diaudit kepada BEl dengan tepat waktu periode 2005-2007. Dari screening yang telah dilakukan diperoleh 112 badan usaha yang secara konsisten tepat waktu menyampaikan laporan keuangan periode 2005-2007. Penarikan sampel dilakukan dengan teknik simple random sampling menggunakan pendekatan Yamane (1973) dalam Ferdinand (2006) dengan rumus $n=N /\left(1+\mathrm{Nd}^{2}\right)$, dimana $n$ adalah jumlah sampel, $\mathrm{N}$ adalah ukuran populasi, dan d adalah presisi yang ditetapkan atau persentase kelonggaran ketidaktelitian karena kesalahan pengambilan sampel yang masih dapat ditoleransi atau diinginkan. Dengan menggunakan $d=10 \%$, maka diperoleh sampel sebanyak 53 badan usaha.

Data laporan keuangan yang telah diaudit diperoleh dari situs BEI (www.idx.co.id), Indonesian Capital Market Directory (ICMD), dan situs resmi masing-masing badan usaha. Data harga saham diperoleh melalui situs http://finance.yahoo.com. Sedangkan data status kewarganegaraan CEO didapatkan melalui annual report masing-masing badan usaha dan situs-situs media massa.

Variabel dan Definisi Operasional Variabel seperti terlihat pada Tabel 2 berikut:

Tabel 2

Variabel, Definisi, dan Pengukurannya

\begin{tabular}{|l|l|l|}
\hline \multicolumn{1}{|c|}{ Variabel } & \multicolumn{1}{|c|}{ Definisi } & \multicolumn{1}{c|}{ Pengukuran } \\
\hline MANAGERSHARE & $\begin{array}{l}\text { Kepemilikan } \\
\text { manajerial }\end{array}$ & $\begin{array}{l}\text { proporsi kepemilikan saham oleh pihak manajer } \\
\text { terhadap jumlah lembar saham yang beredar }\end{array}$ \\
\hline BOARDSIZE & $\begin{array}{l}\text { Ukuran dewan } \\
\text { komisaris }\end{array}$ & jumlah orang yang duduk sebagai dewan komisaris \\
\hline OUTSIDE & $\begin{array}{l}\text { Komisaris } \\
\text { independen }\end{array}$ & $\begin{array}{l}\text { proporsi anggota dewan komisaris yang dipilin } \\
\text { karena keahlian atau pengetahuan yang dimiliki } \\
\text { terhadap jumlah dewan komisaris }\end{array}$ \\
\hline CONCENT & $\begin{array}{l}\text { Komisaris } \\
\text { independen }\end{array}$ & $\begin{array}{l}\text { proporsi anggota dewan komisaris yang dipilin } \\
\text { karena keahlian atau pengetahuan yang dimiliki } \\
\text { terhadap jumlah dewan komisaris }\end{array}$ \\
\hline DEBT & Utang & perbandingan utang total terhadap ekuitas total \\
\hline CEOFOREIGN & $\begin{array}{l}\text { CEO ekspatriat } \\
\text { atau lokal }\end{array}$ & $\begin{array}{l}\text { digunakan variabel dummy, yaitu } 1 \text { untuk CEO } \\
\text { ekspatriat dan 0 untuk CEO lokal }\end{array}$ \\
\hline FIRMSIZE & Ukuran badan & Ukuran badan usaha dalam penelitian ini \\
\hline
\end{tabular}




\begin{tabular}{|l|l|l|}
\hline & Usaha & menggunakan natural log (Ln) aset total \\
\hline SD $_{\mathrm{ij}}$ & $\begin{array}{l}\text { Sectoral } \\
\text { Dummies }\end{array}$ & $\begin{array}{l}\text { Sembilan (9) variabel dummy yang mewakili tiap- } \\
\text { tiap sektor }\end{array}$ \\
\hline MANAGERSHAREQ & Bentuk kuadrat & Kuadrat dari kepemilikan manajerial \\
\hline BOARDSIZEQ & Bentuk kuadrat & Kuadrat dari ukuran dewan komisaris \\
\hline CONCENTQ & Bentuk kuadrat & Komisaris independen \\
\hline ROA & Return on Asset & perbandingan net profit dengan total assets \\
\hline ROE & $\begin{array}{l}\text { Return on } \\
\text { Equity }\end{array}$ & $\begin{array}{l}\text { rasio laba bersih sesudah pajak terhadap modal } \\
\text { sendiri }\end{array}$ \\
\hline PER & $\begin{array}{l}\text { Price Earning } \\
\text { Ratio }\end{array}$ & $\begin{array}{l}\text { rasio antara harga saham perlembar dengan laba } \\
\text { perlembar saham }\end{array}$ \\
\hline Tobins'Q & $\begin{array}{l}\text { Modified } \\
\text { Tobins"Q }\end{array}$ & $\begin{array}{l}\text { nilai kapitalisasi saham pada akhir tahun (year end } \\
\text { market capitalization) terhadap nilai buku aset } \\
\text { total (book value of total assets) }\end{array}$ \\
\hline
\end{tabular}

Model yang digunakan dalam penelitian adalah regresi berganda. Levine et al. (2006:577) merumuskan model regresi berganda dengan $\mathrm{k}$ variabel independen:

$$
Y_{i}=\beta_{0}+\beta_{1} X_{1 i}+\beta_{2} X_{2 i}+\beta_{3} X_{3 i}+\ldots+\beta_{k} X_{k i}+\mu_{i}
$$

Penelitian ini merupakan replikasi dari penelitian Sanda et al. (2005). Ada tujuh model yang dikembangkan oleh Sanda et al. dan masing-masing terbagi atas 4 persamaan, karena ada 4 variabel dependen, yaitu ROA, ROE, PER, dan TOBINS'Q. Model 1 merupakan model induk yang menggunakan variabel independen kepemilikan manajerial (MANAGERSHARE), ukuran dewan komisaris (BOARDSIZE), komisaris independen (OUTSIDE), dan konsentrasi kepemilikan (CONCENT).

$R O A=\beta_{0}+\beta_{1} M A N A G E R S H A R E_{i}+\beta_{2}$ BOARDSIZE $_{i}+\beta_{3} O_{\text {OUTSIDE }}$

$+\beta_{4} \mathrm{CONCENT}_{i}+\mu_{i}$

$R O E=\beta_{0}+\beta_{1}$ MANAGERSHARE ${ }_{i}+\beta_{2}$ BOARDSIZE $_{i}+\beta_{3}$ OUTSIDE $_{i}$

$+\beta_{4} C O N C E N T_{i}+\mu_{i}$

PER $=\beta_{0}+\beta_{1}$ MANAGERSHARE ${ }_{i}+\beta_{2}$ BOARDSIZE $_{i}+\beta_{3}$ OUTSIDE $_{i}$

$+\beta_{4} \mathrm{CONCENT}_{i}+\mu_{i}$

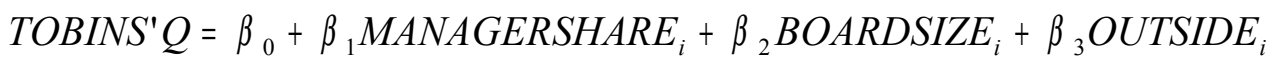

$+\beta_{4} \mathrm{CONCENT}+\mu_{i}$

Model regresi 1 merupakan model regresi yang akan dikenai uji normalitas dan uji asumsi klasik. Uji normalitas menggunakan One Sample Kolmogorov Smirnov. Uji autokorelasi, multikolinearitas, dan heteroskedastisitas menggunakan uji Glejser. Jika data tidak lolos uji normalitas dan asumsi klasik, maka dilakukan transformasi data. Transformasi data dapa† 
dilakukan antara lain dengan menggunakan logaritma, logaritma natural, atau bentuk turunan pertama.

Model 2 hingga 7 dalam penelitian Sanda et al. merupakan pengembangan dari model 1 dengan menambahkan secara bertahap variabel independen kuadratik kepemilikan manajerial (MANAGERSHAREQ), kuadratik ukuran dewan komisaris (BOARDSIZEQ), kuadratik konsentrasi kepemilikan (CONCENTQ), CEO ekspatriat (CEOFOERIGN) sebagai variabel kontrol, utang (DEBT), ukuran badan usaha (FIRMSIZE) sebagai variabel kontrol, dan sectoral dummy $\left(D_{\mathrm{j}}\right)$ terdiri dari 9 sektor juga sebagai variabel kontrol. Penelitian ini hanya berfokus pada model 7 yang merupakan model terakhir dalam penelitian Sanda et al. dengan perluasan variabel independen yang paling lengkap meliputi variabel kuadratik untuk mendeteksi pengaruh nonlinear dan variabel kontrol.

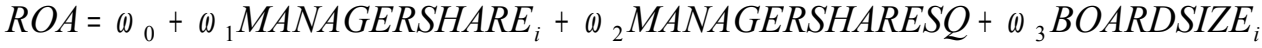

$$
\begin{aligned}
& +\omega_{4} \text { BOARDSIZESQ }+\omega_{5} \text { OUTSIDE }_{i}+\omega_{6} \text { CONCENT }_{i}+\omega_{7} \text { CONCENTSQ } \\
& +\omega_{8} \text { CEOFOREIGN + } \omega_{9} \text { FIRMSIZE }+\omega_{10} D E B T+\sum \theta_{j} D_{j i}+\mu
\end{aligned}
$$

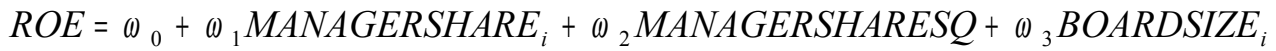

$$
\begin{aligned}
& +\omega_{4} \text { BOARDSIZESQ }+\omega_{5} \text { OUTSIDE }_{i}+\omega_{6} \text { CONCENT }_{i}+\omega_{7} \text { CONCENTSQ } \\
& +\omega_{8} \text { CEOFOREIGN + } \omega_{9} \text { FIRMSIZE + } \omega_{10} D E B T+\sum \theta_{j} D_{j i}+\mu
\end{aligned}
$$

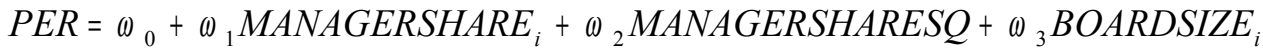

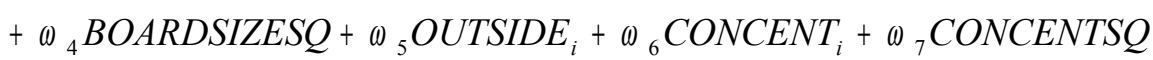

$$
\begin{aligned}
& +\omega_{8} \text { CEOFOREIGN + } \omega_{9} \text { FIRMSIZE + } \omega_{10} D E B T+\sum \theta_{j} D_{j i}+\mu_{i}
\end{aligned}
$$

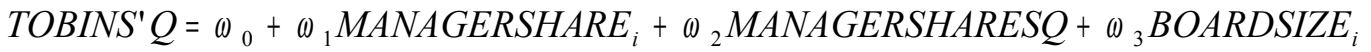

$+\omega_{4}$ BOARDSIZESQ $+\omega_{5}$ OUTSIDE $_{i}+\omega_{6}$ CONCENT $_{i}+\omega_{7}$ CONCENTSQ

$+\omega_{8}$ CEOFOREIGN + $\omega_{9}$ FIRMSIZE $+\omega_{10} D E B T+\sum \theta_{j} D_{j i}+\mu_{i}$

\section{HASIL DAN PEMBAHASAN}

Hasil pengolahan statistik deskriptif berupa nilai rata-rata (mean), standar deviasi, varians, nilai maksimum dan nilai minimum ditampilkan pada tabel 3.

\section{Tabel 3}

Data Deskriptif Variabel Penelitian pada Badan Usaha-Badan Usaha Yang Terdaftar Di BEl Periode 2005-2007

\begin{tabular}{|l|r|r|r|r|r|}
\hline & \multicolumn{1}{|c|}{ N } & Minimum & Maximum & \multicolumn{1}{c|}{ Mean } & Std. Deviation \\
\hline ROA & 159 & $-3,3908$ & 0,6927 & 0,0313 & 0,2941 \\
ROE & 159 & $-3,6593$ & 4,4231 & 0,1098 & 0,4898 \\
PER & 159 & $-73,0894$ & 436,5075 & 21,9502 & 58,1032
\end{tabular}


Jurnal Manajemen Teori dan Terapan | Tahun 3, No. 2, Agustus 2010 | Filia Puspitasari dan Endang Ermawati

\begin{tabular}{|l|r|r|r|r|r|} 
Tobins'Q & 159 & 0,0079 & 3,5585 & 1,1302 & 2,9691 \\
MANAGERSHARE & 159 & 0,0000 & 0,5100 & 0,0107 & 0,0687 \\
BOARDSIZE & 159 & 2 & 12 & 4,82 & 1,964 \\
OUTSIDE & 159 & 0,0000 & 0,7143 & 0,3484 & 0,1542 \\
CONCENT & 159 & 0,1081 & 0,9795 & 0,5497 & 0,2128 \\
CEOFOREIGN & 159 & 0 & 1 & 0,33 & 0,473 \\
DEBT & 159 & $-2,4125$ & 20,2542 & 2,4249 & 3,6926 \\
Valid N (listwise) & 159 & & & & \\
\hline
\end{tabular}

Sumber: Situs resmi badan usaha yang bersangkutan, situs BEl, dan

http://finance.yahoo.com/ (data diolah)

Hasil uji normalitas menunjukkan bahwa hampir seluruh variabel memiliki tingkat signifikansi kurang dari 5\%, yang berarti data tidak berdistribusi normal. Namun, karena jumlah observasi cukup besar, yaitu 159, maka data dianggap berdistribusi normal. Hal ini sesuai dengan pernyataan Gujarati (1995: 103) bahwa apabila ada sejumlah besar variabel independen dan secara identik berdistribusi acak, maka dengan sedikit pengecualian data tersebut cenderung berdistribusi normal.

Pengolahan data dimulai dari variabel-variabel yang menyangkut mekanisme internal badan usaha. Variabel(sekaligus menjadi dimensi corporate governance) tersebut adalah kepemilikan manajerial, ukuran dewan komisaris, komisaris indepeden dan konsentrasi kepemilikan. Variabel dependen adalah ROA, ROE, PER dan Tobins'Q. Model 1 merupakan model regresi induk. Kemudian, model 1 ini diperluas menjadi model 2, 3, 4, 5, 6, dan 7.

Tabel 4

Hasil Regresi Model 7

\begin{tabular}{|l|c|c|c|c|}
\hline & \multicolumn{4}{|c|}{ Variabel dependen } \\
\cline { 2 - 5 } & ROA & ROE & PER & TOBINS'Q \\
\hline \multirow{2}{*}{ MANAGERSHARE } & 1,371 & $-3,961$ & $-140,771$ & $-68,821$ \\
& $(0,848)$ & $(0,750)$ & $(0,927)$ & $(0,376)$ \\
\hline MANAGERSHAREQ & $-2,013$ & 8,953 & 185,971 & 134,723 \\
& $(0,887)$ & $(0,716)$ & $(0,951)$ & $(0,380)$ \\
\hline BOARDSIZE & 0,039 & 0,103 & $-17,210$ & 0,610 \\
& $(0,489)$ & $(0,300)$ & $(0,161)$ & $(0,323)$ \\
& & & & \\
\hline BOARDSIZEQ & $-0,004$ & $-0,009$ & 0,797 & $-0,033$ \\
& $(0,441)$ & $(0,300)$ & $(0,447)$ & $(0,533)$ \\
\hline OUTSIDE & $-0,189$ & $-0,280$ & 52,371 & 0,293 \\
& $(0,247)$ & $(0,324)$ & $(0,137)$ & $(0,868)$ \\
\hline CONCENT & 0,138 & $-0,744$ & 10,062 & 2,305 \\
& $(0,795)$ & $(0,418)$ & $(0,929)$ & $(0,687)$ \\
\hline CONCENTQ & $-0,028$ & 0,760 & $-22,460$ & $-2,241$ \\
& $(0,954)$ & $(0,358)$ & $(0,826)$ & $(0,664)$ \\
\hline CEOFOREIGN & $-0,113$ & $-0,210$ & 14,642 & 1,015 \\
& $(0,047)^{* *}$ & $(0,033)^{* *}$ & $(0,229)$ & $(0,099)^{*}$ \\
\hline DEBT & $-0,018$ & $-0,021$ & $-0,883$ & 0,005 \\
& $(0,028)^{* *}$ & $(0,138)$ & $(0,612)$ & $(0,954)$ \\
\hline FIRMSIZE & 0,072 & 0,093 & 5,154 & $-0,425$ \\
\hline
\end{tabular}


Jurnal Manajemen Teori dan Terapan | Tahun 3, No. 2, Agustus 2010 | Filia Puspitasari dan Endang Ermawati

\begin{tabular}{|l|c|c|c|c|}
\hline & $(0,000)^{* * *}$ & $(0,001)^{* * *}$ & $(0,115)$ & $(0,010)^{* * *}$ \\
\hline Agriculture & 0,028 & $-0,068$ & 3,348 & $-0,040$ \\
& $(0,820)$ & $(0,751)$ & $(0,900)$ & $(0,976)$ \\
\hline Basiclnd & 0,052 & 0,281 & 41,854 & $-0,144$ \\
& $(0,569)$ & $(0,077)^{*}$ & $(0,034)^{* *}$ & $(0,884)$ \\
\hline Consumer & 0,166 & 0,246 & 0,875 & 1,118 \\
& $(0,137)$ & $(0,202)$ & $(0,971)$ & $(0,353)$ \\
\hline Infrastructure & $-0,131$ & $-0,138$ & 38,171 & 1,344 \\
& $(0,187)$ & $(0,424)$ & $(0,075)$ & $(0,212)$ \\
\hline Mining & 0,000 & 0,008 & $-4,788$ & 1,852 \\
& $(0,998)$ & $(0,964)$ & $(0,823)$ & $(0,087)^{*}$ \\
\hline Misclnd & 0,028 & 0,095 & $-9,131$ & $-0,448$ \\
& $(0,834)$ & $(0,681)$ & $(0,749)$ & $(0,756)$ \\
\hline Property & 0,002 & $-0,013$ & 11,964 & $-0,159$ \\
& $(0,979)$ & $(0,935)$ & $(0,538)$ & $(0,871)$ \\
\hline Trade & $-0,052$ & $-0,026$ & 2,040 & 0,977 \\
& $(0,477)$ & $(0,836)$ & $(0,896)$ & $(0,215)$ \\
\hline$R^{2}$ & 0,258 & 0,193 & 0,121 & 0,145 \\
\hline F & $0,001^{* * *}$ & $0,023^{* *}$ & 0,390 & 0,183 \\
\hline
\end{tabular}

${ }^{(*)}$ signifikan $10 \%,{ }^{(* *)}$ signifikan $5 \%,{ }^{(* * *)}$ signifikan $1 \%$

Model 7 merupakan perluasan dari model 1 hingga 6, dengan penambahan utang sebagai leverage badan usaha. Dalam penelitian ini, utang tidak dimasukkan ke dalam mekanisme internal badan usaha melainkan sebagai mekanisme eksternal, karena terkait dengan pihak di luar badan usaha. Hasil yang diperoleh, model regresi dengan variabel dependen ROA dan ROE yang signifikan.

Pembahasan hasil penelitian dilakukan pada model 7, karena model 7 terdiri dari variabel independen paling lengkap, yaitu 5 dimensi corporate governance yang terdiri dari mekanisme internal dan mekanisme eksternal beserta variabel kuadratik (kepemilikan manajerial, kepemilikan manajerial kuadrat, ukuran dewan komisaris, ukuran dewan komisaris kuadrat, komisaris independen, konsentrasi kepemilikan, konsentrasi kepemilikan kuadrat dan utang), dummy variable CEO ekspatriat, control variable aset total, dan sectoral dummies.

Kepemilikan manajerial berpengaruh negatif terhadap semua variabel dependen, kecuali terhadap ROA yang berpengaruh positif. Hasil uji secara parsial (uji t) tidak menunjukkan pengaruh signifikan kepemilikan manajerial. Hal ini tidak mendukung hasil penelitian Gudono (2000) dan Mehran (1994), yaitu kepemilikan saham oleh pihak manajer memiliki pengaruh signifikan positif terhadap kinerja keuangan. Dalam hubungannya dengan efek nonlinear, kepemilikan manajerial kuadrat memiliki pengaruh sebaliknya, yaitu positif tidak signifikan terhadap ROE, PER dan Tobins'Q. Jika digambarkan dengan kurva nonlinear, kepemilikan manajerial tersebut berbentuk U. Pada awalnya, peningkatan kepemilikan manajerial akan 
berpengaruh negatif pada kinerja kevangan badan usaha karena pihak manajer yang hanya memiliki persentase saham dalam jumlah kecil (minoritas) akan membuat pemegang saham lain akan berusaha mengawasi dan mempengaruhi pengambilan keputusan oleh manajer. Dengan demikian, proses keputusan yang diambil tidak fleksibel dan lebih lambat. Hal ini mungkin terjadi mengingat terdapat sifat paternalistik di Indonesia, di mana pemegang saham mayoritas masih ingin ikut serta dalam pengambilan keputusan manajerial. Trend ini berubah pada titik tertentu, yaitu menjadi positif. Persentase saham yang dimiliki pihak manajer meningkat, sehingga pihak manajer tidak menjadi pemegang saham minoritas.

Pihak manajer lebih memiliki kekuasaan mengambil keputusan daripada sebelumnya sehingga proses pengambilan keputusan lebih cepat dan fleksibel. Hal ini berdampak positif terhadap kinerja keuangan badan usaha. Hasil penelitian bahwa kepemilikan manajerial kuadrat berpengaruh positif tidak signifikan terhadap ROE, PER dan Tobins'Q kurang mendukung Gudono (2000) dan Mehran (1994). Kedua peneliti tersebut menyatakan bahwa kepemilikan manajerial berpengaruh signifikan positif terhadap kinerja keuangan badan usaha. Insentif berupa saham yang diberikan kepada pihak manajer memacu pihak manajer untuk bekerja lebih keras dan cerdas dalam meningkatkan nilai badan usaha, yang juga merupakan milik pihak manajer.

Efek nonlinear kepemilikan manajerial terhadap ROA adalah kepemilikan manajerial berpengaruh positif pada kondisi awal, kemudian pada titik tertentu pengaruh tersebut berubah menjadi negatif. Penjelasan untuk hal tersebut berkaitan dengan managerial entrenchment theory. Jong dan Veld (2000) mengemukakan bahwa pada umumnya, besarnya kompensasi yang diberikan kepada pihak manajer tergantung oleh besarnya aset badan usaha yang dikelola serta efektivitas pihak manajer dalam mengelola aset tersebut. Ketika pihak manajer memiliki sedikit saham, maka pihak manajer giat dalam mengelola aset badan usaha, demi mendapatkan kompensasi. Kompensasi yang diperoleh dapat berupa kepemilikan (saham) atau opsi. Hal ini memacu pihak manajer untuk meningkatkan nilai ROA. Namun, ketika kepemilikan oleh pihak manajer semakin tinggi, maka pihak manajer ingin mempertahankan kekayaan badan usaha (yang juga merupakan milik pihak manajer). Pihak manajer tidak berani mengambil proyek-proyek yang memiliki risiko tinggi, karena pihak manajer mengganggap hal tersebut dapat meningkatkan risiko kehilangan kekayaan yang dimilikinya. Proyek yang memiliki risiko rendah menjadi pilihan pihak manajer sehingga tingkat hasil atas proyek yang diambil juga rendah. Hal ini dapat membawa pengaruh negatif terhadap nilai ROA. 
Efek nonlinear kepemilikan manajerial terhadap ROE, PER dan Tobins'Q mendukung hasil penelitian Sanda et al. (2005), yaitu kepemilikan manajerial berpengaruh negatif terhadap kinerja keuangan pada awalnya, kemudian setelah melewati titik tertentu akan berpengaruh positif. Adanya efek nonlinear kepemilikan manajerial terhadap kinerja keuangan ini mendukung hasil penelitian Short dan Keasey (1999) dalam Nur (2007) dan Sanda et al. (2005), yaitu terdapat hubungan nonlinear antara kepemilikan manajerial dengan nilai badan usaha.

Efek nonlinear ukuran dewan komisaris dimiliki oleh model regresi dengan semua variabel dependen. Ukuran dewan komisaris berpengaruh positif terhadap ROA, ROE, dan Tobins' $Q$ pada mulanya, kemudian memiliki pengaruh berlawanan setelah melewati titik tertentu. Dalam konteks nonlinear, ukuran dewan komisaris (ukuran dewan komisaris kuadrat) memiliki pengaruh berlawanan dengan kondisi semula, yaitu negatif tidak signifikan terhadap ROA, ROE, dan Tobins' $Q$. Ukuran komisaris optimal merupakan titik maksimal jumlah komisaris agar kinerja keuangan meningkat. Dalam penelitian Sanda et al. (2005), jumlah optimal adalah 10. Melewati titik tersebut, berarti badan usaha telah mempekerjakan terlalu banyak komisaris sehingga kinerja keuangan menurun. Ketika ukuran dewan komisaris di bawah titik optimal, peningkatan jumlah dewan komisaris hingga titik tersebut akan meningkatkan kinerja keuangan badan usaha. Komisaris ditunjuk untuk mewakili pemegang saham mengawasi operasional badan usaha. Peningkatan jumlah komisaris (hingga di bawah titik optimal) menyebabkan adanya pengawasan lebih ketat terhadap pihak manajer, sehingga pihak manajer lebih giat dalam meningkatkan performa badan usaha dan kemungkinan timbul penyelewengan terhadap sumber daya badan usaha rendah. Namun, setelah melewati titik optimal, jumlah komisaris terlalu banyak. Akibatnya, proses pengambilan keputusan berjalan lebih lamban karena harus meminta pendapat semua komisaris. Keputusan menjadi tidak fleksibel. Karena ketidakefektifan pengambilan keputusan, maka peluang-peluang bisnis yang ada tidak dimanfaatkan dengan maksimal. Secara langsung, hal ini berdampak pada penurunan kinerja badan usaha. Ukuran dewan komisaris berpengaruh negatif (setelah melewati titik tertentu) terhadap kinerja keuangan badan usaha (ROA, ROE, dan Tobins'Q) mendukung hasil penelitian Yang et al. (2006).

Ukuran dewan komisaris berpengaruh negatif terhadap PER, kemudian pada titik tertentu berpengaruh positif. Hal ini mengindikasikan tingkat kepercayaan investor yang rendah jika jumlah komisaris bertambah hingga mencapai titik tertentu. Harga saham dapat mencerminkan tingkat kepercayaan investor terhadap ukuran dewan komisaris. Ketika jumlah anggota dewan komisaris ditambah, dan komisaris baru tersebut dianggap kurang kompeten atau semakin mengabaikan kepentingan pemegang saham minoritas, maka 
investor dan pemegang saham minoritas akan memandang sisi buruk dari penambahan komisaris tersebut. Efek nonlinear berupa pengaruh positif terhadap PER mengindikasikan bahwa jika terlalu banyak anggota dewan komisaris non independen, maka pengangkatan komisaris berikutnya adalah komisaris independen. Sesuai dengan pedoman GCG (2006) bahwa komisaris independen diperlukan untuk menjamin mekanisme pengawasan berjalan secara efektif sesuai peraturan perundang-undangan. Investor memandang baik terhadap komisaris independen. Dengan demikian harga pasar saham meningkat, diikuti peningkatan nilai PER.

Komisaris independen berpengaruh negatif tidak signifikan terhadap ROA dan ROE serta berpengaruh positif tidak signifikan terhadap PER dan Tobins' $Q$. Dalam hal ROA dan ROE, hasil penelitian ini mendukung Sanda et al. (2005) yang menyatakan bahwa komisaris independen tidak memberikan kontribusi yang positif bagi kinerja keuangan badan usaha. Sebaliknya, komisaris independen berpengaruh positif tidak signifikan terhadap PER dan Tobins'Q. Investor menganggap komisaris independen lebih bersikap netral terhadap kebijakan pihak manajer dan lebih memperjuangkan kepentingan pemegang saham minoritas. Oleh karena itu, tingkat kepercayaan investor meningkat dengan adanya komisaris independen, sehingga harga saham meningkat dan secara langsung meningkatkan nilai PER dan Tobins'Q. Rosenstein dan Wyatt (1990) dalam Mehran (1994) menyatakan bahwa penunjukkan komisaris independen berpengaruh positif terhadap harga saham secara rata-rata. Dengan kata lain akan meningkatkan nilai PER (Price per Earning Ratio). Kenaikan harga saham tersebut mengindikasikan kepercayaan investor terhadap komisaris independen, yang dianggap lebih tidak memihak dalam menjalankan fungsinya sebagai wakil pemegang saham. Fama dan Jensen (1983) dalam Nur (2007) menyatakan bahwa komisaris independen akan lebih efektif dalam memonitor pihak manajer. Pemonitoran oleh komisaris independen atau eksternal dinilai mampu memecahkan masalah keagenan. Selain itu, komisaris independen dapat memberikan kontribusi terhadap nilai badan usaha. Komisaris independen dapat memberikan kontribusi terhadap nilai badan usaha melalui aktivitas evaluasi dan keputusan stratejik. Informasi yang diberikan tersebut diharapkan mampu menjadi panduan bagi pihak manajer dalam menjalankan badan usaha. Dengan demikian, potensi mismanagement yang berakibat pada kesulitan keuangan dapat diminimumkan. Berkurangnya mismanagement menyebabkan peningkatan kinerja badan usaha, karena efektivitas dan efisiensi pengelolaan akan tercapai. Dengan demikian, penambahan komisaris independen dianggap sebagai hal positif oleh investor, sehingga dapat meningkatkan harga saham. 
Konsentrasi kepemilikan memiliki efek nonlinear terhadap kinerja keuangan badan usaha. Hasil model regresi 7 menunjukkan bahwa konsentrasi kepemilikan memiliki efek nonlinear terhadap ROA, ROE, PER dan Tobins'Q. Terkait dengan rasio profitabilitas, yaitu ROE, konsentrasi kepemilikan berpengaruh negatif pada titik awal, namun pengaruh tersebut berubah menjadi positif setelah melewati titik tertentu. Ketika konsentrasi kepemilikan masih relatif kecil, maka masing-masing pemegang saham merasa memiliki tingkat kekuasaan yang sama kuat dalam mempengaruhi pengambilan keputusan melalui dewan komisaris. Karena setiap pemegang saham memiliki pendapat yang berbeda, maka kesatuan pendapat akan sulit dicapai. Masing-masing pemegang saham menghendaki pihak manajer bertindak sesuai dengan keinginan masing-masing pemegang saham. Dengan demikian, ketidakefisienan pengambilan keputusan (terutama yang dapat mempengaruhi kinerja pihak manajer) akan terjadi. Namun, pada titik tertentu, yaitu ketika konsentrasi kepemilikan semakin tinggi, pemegang saham yang dapat dikatakan sebagai pemegang saham mayoritas tersebut telah memiliki kekuasaan yang lebih mutlak dalam mempengaruhi pengambilan keputusan melalui dewan komisaris. Kerja sama dengan pihak manajer akan lebih mudah tercapai karena tujuan yang ingin dicapai tidak beragam, seperti ketika konsentrasi kepemilikan rendah.

Pengambilan keputusan oleh pihak manajer akan lebih terarah dan dapat lebih efisien dalam meningkatan ROE. Dengan konsentrasi kepemilikan yang tinggi, Drobetz et al. (2004) menyatakan bahwa terjadi peningkatan hak atas aliran kas dari pemegang saham terbesar, maka akan menimbulkan dampak positif pada nilai saham yang dimiliki (pemegang saham terbesar). Dengan demikian, para pemegang saham tersebut akan memiliki insentif dalam meningkatkan kualitas corporate governance badan usaha yang bersangkutan.

Konsentrasi kepemilikan berpengaruh positif terhadap market ratio, yaitu PER dan Tobins'Q, namun setelah melewati titik tertentu, pengaruh tersebut berubah menjadi negatif. Analisis untuk hal ini adalah investor (calon investor) yang akan menanamkan modalnya dalam suatu badan usaha akan melihat struktur kepemilikan dalam badan usaha tersebut. Sebuah badan usaha yang memiliki konsentrasi kepemilikan rendah menjadi lebih menarik bagi investor, karena pengaruh pemegang saham mayoritas tidak mutlak. Dalam diri investor, terdapat keinginan untuk ikut serta dalam pengambilan keputusan badan usaha. Semakin menyebarnya konsentrasi kepemilikan, maka hak penyampaian pendapat pemegang saham (investor) hampir sama. Dengan demikian, baik investor yang ingin memiliki sebagian kecil saham atau pemegang saham minoritas tetap memiliki kesempatan mempengaruhi pengambilan keputusan dalam badan usaha melalui dewan komisaris. Karena alasan 
tersebut, harga saham semakin tinggi, yang berdampak pada kenaikan nilai PER dan Tobins'Q. Semakin tinggi konsentrasi kepemilikan akan menimbulkan adanya kekuasaan pemegang saham mayoritas. Investor memandang hal ini sebagai sesuatu yang buruk.

Dengan adanya pemegang saham mayoritas (dengan persentase kepemilikan saham tinggi), maka pemegang saham minoritas tidak memiliki andil yang juga minoritas dalam badan usaha. Segala keputusan melalui dewan komisaris ditentukan oleh pemegang saham mayoritas. Pandangan investor mengenai hal tersebut tercermin dari rendahnya harga saham badan usaha, yang berdampak terhadap menurunnya nilai PER dan Tobins'Q. Hasil penelitian tersebut tidak mendukung Chantrataragul (2007) meneliti mengenai konsentrasi kepemilikan dalam hubungannya dengan kinerja keuangan badan usaha di Thailand dan menemukan hasil penelitian semakin tinggi konsentrasi kepemilikan, maka akan menghasilkan kinerja keuangan yang lebih baik (terutama dalam hal Tobin's Q). Hasil penelitian pengaruh non linear konsentrasi kepemilikan terhadap market ratio (PER dan Tobins'Q) mendukung hasil penelitian Sanda et al. (2005), yaitu konsentrasi kepemilikan berpengaruh positif terhadap PER dan Tobins' $Q$ pada awalnya, namun setelah melewati titik tertentu, konsentrasi kepemilikan berpengaruh negatif terhadap PER dan Tobins' $Q$.

Utang sebagai mekanisme eksternal corporate governance dimasukkan ke dalam model regresi untuk melengkapi pengaruh mekanisme corporate governance terhadap kinerja badan usaha. Hasil model regresi 7 menunjukkan bahwa utang berpengaruh negatif terhadap semua variabel dependen, kecuali terhadap Tobins'Q. Namun nilai koefisien utang terhadap Tobins' $Q$ dan nilai uji † sangat kecil, sehingga dianggap tidak berpengaruh. Utang berpengaruh signifikan negatif terhadap ROA. Pengaruh negatif utang terhadap ROA, ROE dan PER mendukung hasil penelitian Tandelilin dan Wilberforce (2000) bahwa utang berpengaruh negatif tidak signifikan terhadap kinerja kevangan badan usaha, terutama dalam hal profitabilitas. Sanda et al. (2005) menyatakan pengaruh negatif disebabkan adanya kemungkinan konflik kepentingan antara pihak debtholder (yang biasanya memiliki perwakilan dalam dewan komisaris) dengan pemegang saham. Debtholder menginginkan badan usaha memiliki stabilitas agar dapat membayar utang, sehingga debtholder tidak menghendaki adanya strategi badan usaha yang mengancam kemampuan badan usaha untuk membayar utang. Sedangkan pemegang saham bertujuan memaksimumkan kemakmurannya, sehingga pemegang saham menginginkan badan usaha melakukan strategi yang dapat menaikkan harga saham.

Dari hasil model 7, dapat diketahui bahwa CEO ekspatriat berpengaruh positif tidak signifikan terhadap PER dan signifikan pada 10\% terhadap Tobins'Q, serta berpengaruh 
signifikan negatif terhadap ROA dan ROE. Pengaruh positif CEO ekspatriat terhadap PER dan Tobins'Q mendukung Sanda et al. (2005), yang menyatakan CEO ekspatriat cenderung memiliki kinerja yang lebih baik daripada CEO lokal. CEO ekspatriat dianggap memiliki pengetahuan dan keahlian dari negara asalnya sehingga terjadi knowledge spillover atau technology spillover ke Indonesia. CEO ekspatriat yang bekerja di Indonesia kebanyakan berasal dari Jepang, Australia, Jerman, dan negara lain yang memiliki tingkat teknologi dan keahlian lebih tinggi dari Indonesia. Tingkat kepercayaan investor terhadap CEO ekspatriat tercermin dari harga saham yang tinggi, sehingga meningkatkan nilai PER dan Tobins'Q. CEO ekspatriat memiliki pengaruh signifikan negatif terhadap ROA dan ROE (rasio profitabilitas). Setiap badan usaha memiliki risiko ketika mempekerjakan CEO asing. Salah satu risiko yang harus dihadapi oleh badan usaha adalah perbedaan budaya (Moin, 2003:287). Dari badan usaha-badan usaha obyek penelitian yang memiliki CEO asing, sebesar lebih dari 50\% (mayoritas) merupakan badan usaha yang telah diakuisisi oleh pihak asing (dapat dilihat pada Lampiran 14). Karena berasal dari negara yang memiliki perbedaan budaya dengan Indonesia, CEO ekspatriat memiliki kemungkinan kurang pemahaman mengenai badan usaha di Indonesia, sehingga kinerjanya tidak optimal. Hal ini dapat mengakibatkan kegagalan dalam meningkatkan nilai badan usaha. Kegagalan ini dapat mengelola badan usaha tercermin dari nilai ROA dan ROE.

Control variable aset total berpengaruh signifikan positif terhadap ROA dan ROE. Hal ini mengindikasikan ukuran badan usaha yang semakin besar (semakin besar aset total) akan mendukung efektivitas mekanisme corporate governance. Didukung jumlah aset yang lebih besar, maka pengaplikasian mekanisme corporate governance (kepemilikan manajerial, penentuan ukuran dewan komisaris, penentuan proporsi komisaris independen, konsentrasi kepemilikan dan utang) dalam suatu badan usaha akan membawa dampak positif bagi rasio profitabilitas badan usaha (ROA dan ROE). Control variable aset total berpengaruh positif, namun tidak signifikan terhadap PER. Hal ini mengindikasikan semakin besar ukuran badan usaha, akan mendukung kualitas pelaksanaan corporate governance, sehingga meningkatkan nilai PER. Pengaruh signifikan negatif terjadi pada control variable aset total terhadap Tobins' $Q$. Hasil penelitian bahwa control variable aset total berpengaruh signifikan negatif terhadap Tobins' $Q$ mendukung Sanda et al. (2005). Dalam kasus Tobins' $Q$, semakin besar aset total yang dimiliki oleh badan usaha, akan mengurangi efektivitas pelaksanaan corporate governance, sehingga mengurangi nilai Tobins' $Q$.

Sectoral dummies ditujukan untuk melihat pengaruh masing-masing sektor terhadap kinerja keuangan, jika badan usaha mengaplikasikan corporate governance. Sektor finance didrop dari proses pengolahan data (excluded variable). Beberapa sektor berpengaruh positif 
terhadap variabel dependen tertentu, mengindikasikan adanya faktor pendukung dalam sektor tersebut dalam rangka menyukseskan corporate governance. Jika terjadi hal sebaliknya, yaitu sectoral dummy berpengaruh negatif terhadap kinerja keuangan, berarti di dalam sektor tersebut terdapat faktor penghambat yang dapat mengurangi efektivitas pelaksanaan corporate governance. Contoh faktor yang dapat mempengaruhi pelaksanaan corporate governance adalah peraturan pemerintah dan kebijakan badan usaha, bentuk pasar, struktur pendanaan masing-masing sektor, dan lain-lain.

\section{SIMPULAN}

Hasil penelitian merupakan hasil model regresi 7 (model regresi terakhir). Dimensi corporate governance yang merupakan mekanisme internal corporate governance (kepemilikan manajerial, ukuran dewan komisaris, komisaris independen, dan konsentrasi kepemilikan) memiliki pengaruh tidak signifikan terhadap ROA, ROE, PER dan Tobins' Q. Adanya pengaruh variabel independen terhadap variabel dependen yang tidak signifikan ini menyebabkan hasil penelitian tidak dapat digeneralisasi. Dimensi corporate governance yang merupakan mekanisme eksternal corporate governance, yakni utang, memiliki pengaruh signifikan negatif terhadap ROA, sedangkan terhadap variabel dependen yang lain tidak berpengaruh signifikan. Dengan demikian, kesimpulan hasil penelitian pengaruh utang terhadap ROE, PER dan Tobins'Q tidak dapat digeneralisasi. Pengaruh signifikan terdapat pada dummy variable CEO ekspatriat terhadap ROA (signifikan pada 5\%), ROE (signifikan pada 5\%) dan Tobins'Q (signifikan pada 10\%).

Penerimaan dan penolakan hipotesis kerja dilakukan berdasarkan hasil penelitian model regresi 7, yaitu pengaruh variabel independen mekanisme corporate governance dan dummy variable CEO ekspatriat terhadap ROE. Seperti telah dijelaskan pada bab IV, ROE merupakan pengukuran kinerja keuangan yang penting. Tujuan utama manajemen keuangan badan usaha adalah memaksimumkan kemakmuran pemilik (pemegang saham). ROE merupakan indikator bagi pemilik (pemegang saham) untuk mengetahui tingkat hasil atas investasi yang telah ditanamkan. Jika badan usaha tidak dapat memberikan tingkat hasil yang semestinya kepada pemilik, maka tujuan badan usaha untuk memaksimumkan kekayaan pemilik telah gagal.

Kepemilikan manajerial sebagai mekanisme internal corporate governance yang digunakan untuk pengujian hipotesis kerja adalah kepemilikan manajerial kuadrat (setelah terjadi efek non linear kepemilikan manajerial). Hasil penelitian menunjukkan bahwa kepemilikan 
manajerial berpengaruh positif tidak signifikan terhadap ROE. Dengan demikian, $\mathrm{H}_{1}$ ditolak, namun arah pengaruh hasil penelitian sesuai dengan hipotesis kerja.

Ukuran dewan komisaris sebagai mekanisme internal corporate governance yang digunakan untuk pengujian hipotesis kerja adalah ukuran dewan komisaris kuadrat (setelah terjadi efek non linear ukuran dewan komisaris). Hasil penelitian menunjukkan bahwa ukuran dewan komisaris berpengaruh negatif tidak signifikan terhadap ROE. Dengan demikian, $\mathrm{H}_{2}$ ditolak, namun arah pengaruh hasil penelitian sesuai dengan hipotesis kerja. Komisaris independen merupakan salah satu mekanisme internal corporate governance. Hasil penelitian menunjukkan bahwa komisaris independen berpengaruh negatif tidak signifikan terhadap ROE. Dengan demikian, $\mathrm{H}_{3}$ ditolak. Komisaris independen tidak memberikan kontribusi dalam peningkatan nilai ROE.

Konsentrasi kepemilikan sebagai mekanisme internal corporate governance yang digunakan untuk pengujian hipotesis kerja adalah konsentrasi kepemilikan kuadrat (setelah terjadi efek non linear konsentrasi kepemilikan). Hasil penelitian menunjukkan bahwa konsentrasi kepemilikan berpengaruh positif tidak signifikan terhadap ROE. Dengan demikian, $\mathrm{H}_{4}$ ditolak, namun arah pengaruh hasil penelitian sesuai dengan hipotesis kerja.

Utang merupakan mekanisme eksternal corporate governance. Hasil penelitian menunjukkan bahwa utang berpengaruh negatif tidak signifikan terhadap ROE. Dengan demikian, $\mathrm{H}_{5}$ ditolak, namun arah pengaruh hasil penelitian sesuai dengan hipotesis kerja.

CEO ekspatriat berpengaruh signifikan negatif terhadap ROE. Dengan demikian, $\mathrm{H}_{6}$ ditolak meskipun signifikan pada $5 \%$ karena memiliki hasil penelitian memiliki arah pengaruh berlawanan dengan hipotesis kerja. Keberadaan CEO ekspatriat tidak memberikan kontribusi bagi peningkatan nilai ROE.

\section{Rekomendasi}

Bagi badan usaha, penelitian ini dapat digunakan sebagai dasar untuk mengaplikasikan dimensi-dimensi corporate governance secara efektif, sesuai dengan hasil penelitian. Pengoptimalan kepemilikan manajerial, ukuran dewan komisaris, proporsi komisaris independen, konsentrasi kepemilikan dan utang yang tepat akan menghasilkan kinerja keuangan yang lebih baik bagi badan usaha, naik dari sisi profitabilitas, maupun rasio pasar. 
Bagi pihak investor, meskipun penelitian ini belum menunjukkan adanya pengaruh yang signifikan dari keseluruhan mekanisme corporate governance terhadap kinerja keuangan badan usaha, namun investor masih dapat mempertimbangkan pengaruh yang signifikan dari beberapa variabel mekanisme corporate governance dan beberapa variabel kontrol terhadap kinerja keuangan. Investor dapat melakukan analisis fundamental suatu badan usaha berdasarkan dimensi-dimensi corporate governance yang dimiliki. Dengan demikian, dapat diambil suatu keputusan investasi yang tepat jika investor ingin menanamkan modalnya. Selebihnya, investor harus memperhatikan faktor-faktor lain di luar mekanisme corporate governance dalam melakukan analisis fundamental.

Saran untuk penelitian selanjutnya yaitu memperbesar jumlah sampel, menambah jumlah periode, serta mempertimbangkan faktor lag terutama dalam hubungannya dengan kinerja pasar. Dengan demikian, hasil penelitian selanjutnya menjadi lebih akurat.

\section{DAFTAR REFERENSI}

Benhart, S. W., dan Rosenstein S., 1998, "Board Composition, Managerial Ownership, and Firm Performance: An Empirical Analysis", Financial Review 33, pp. 1-16.

Chantrataragul, Dusadee, 2007, "Political Connection and Ownership Concentration: Evidence from Thailand", Master of Science Program in Finance (International Program), Faculty of Commerce and Accountancy, Thammasat University, Bangkok, Thailand.

Damodaran, Aswath, 2001, Corporate Finance: Theory and Practice, Second Edition, Hermitage Publishing Services, Wiley International Edition.

Davies, J.R., David Hillier, dan Patrick McColgan, 2002, "Ownership Stucture, Managerial Behavior, and Corporate Value", International Review of Financial Analysis.

Demirguc-Kunt, A, 1992, "Developing Country Capital Structures and Emerging Stock Markets", World Bank Policy Research Working Papers, WPS 933, July, pp. 1-40.

Drobetz, W., K. Gugler, dan S. Hirschvolg, 2004, "The Determinants of the German Corporate Governancerating", Working Paper.

Estrin, S., J. Konings, Z. Zolkiewski, dan M. Angelucci, 2001, "The Effect of Ownership and Competitive Pressure on Firm Performance in Transition Countries: Micro Evidence from Bulgaria, Romania and Poland", a Phare Ace Workshop on Competition Policy in Romania, 7 Agustus 2001.

Ferdinand, Agusty, 2006, Metode Penelitian Manajemen, Badan Penerbit Undip.

Gitman, Lawrence, J., 2003, Principles of Managerial Finance, Tenth Edition, McGrawHill. 
Gudono, 2000, "The Role of Executive Compensation Schemes and Stock Ownership in Corporate Strategy: How They Affect Performance", pp. 121-133.

Gujarati, Damodar N., 1995, Basic Econometrics, Third Edition, International Edition, McGraw Hill International.

Javed, Attiya Y., dan Robina lqbal, 2007, "Relationship between Corporate Governance Indicators and Firm Value: A Case Study of Karachi Stock Exchange", MPRA Paper, Posted 07 November 2007, No.2225.

Jensen, M.C., dan W.H. Meckling, 1976, "Theory of The Firm: Managerial Behaviour, Agency Cost, and Ownership Structure", Journal of Financial and Economics 3, pp. 305-360.

Jong, Abe de, dan Chris Veld, 2000, "An Empirical Analysis of Incremental Capital Structure Decisions Under Managerial Entrenchment", Journal of Banking and Finance.

Kay, Ira T., 1992, "Value of The Top: Solution to The Executive Compensation Crisis", Harper Business, New York, NY.

Laing, D., dan C.M. Weir, 1999, "Governance Structures, Size, and Corporate Performance in UK Firms", Management Decision, 37(5): pp. 457-64.

Lefort, Fernando, dan Eduaro Walker, 2005, "The Effect of Corporate governance Prstices on Company Market Valuation and Dividend Payout Policy in Chile", Business School, Pontificia Universidad Catolica de Chile.

Mehran, Hamid, 1994, "Executive Compensation Structure, Ownership and Firm Performance", Journal of Financial Economics 38, pp. 163-168.

Mitton, T., 2002, "A Cross Firm Analysis of The Impact of Corporate Governance on The East Asian Financial Crisis", Journal of Financial Economics, Vol 2, No. 5.

Moin, Abdul, 2003, Merger, Akuisisi dan Divestasi, Yogyakarta: Ekonisia.

Nor, F.M., R.M. Said, dan H. Redzuan, 1999, "Structure of Ownership and Corporate Financial Performance: A Malaysian Case", Malaysian Management Review, December 1999, pp. 44-48.

Nur, Emrinaldi D.P., "Analisis Pengaruh Praktek Tata Kelola Perusahaan (Corporate governance) Tehadap Kesulitan Keuangan Perusahaan (Financial Distress): Suatu Kajian Empiris", Jurnal Bisnis dan Akuntansi, April 2007, Vol. 9, No. 1, pp. 88-108.

Ruvinsky, Jessica, 2005, "Building a Better Board: How Nonprofit Board Size and Independence Relate to Board Performance", Social Stanford Innovation Review (www.ssireview.com).

Sanda, Ahmadu, Aminu S. Mikaliu, dan Tukur Garba, 2005, "Corporate Governance Mechanism and Firm Financial Performance in Nigeria", African Economic Research Consortium, Nairobi, Maret 2005, Department of Economics, Usmanu Danfodiyo University, Sokoto, Nigeria. 
Siallagan, Hamonangan, dan Mas'ud Machfoedz, 2006, "Mekanisme Corporate Governance, Kualitas Laba dan Nilai Perusahaan", Simposium Nasional Akuntansi Padang 9.

Siswanto, Sutoyo, dan E. John Aldridge, 2005, "Good Corporate Governance: Tata Kelola Perusahaan Yang Sehat", Jakarta: PT Damar Mulai Pustaka.

Situs resmi badan usaha obyek penelitian

Smart, Scott B., William L. Megginson, dan Lawrence J. Gitman, 2004, "Corporate Finance", Southwestern, Ohio.

Sabardi, Agus, 1995, Manajemen Keuangan, Jilid 1, Yogyakarta: AMP YKPN.

Sulistyanto, H.Sri, dan Yusni Warastuti, 2003, "Good Corporate Governance: Harapan dan Tantangan", Jurnal Studi Bisnis, Unika Soegijapranata, 2004, Vol 2, No.1, pp. 53-60.

Tandelilin, Eduaradus, dan Turyasingura Wilberforce, 2000, "Can Debt and Dividend Policies Substitute Insider Ownership in Controlling Equity Agency Conflict?", pp. 157-167.

Weston, J. Fred, dan Thomas Copeland, 1987, Manajemen Kevangan, Jilid 1, Edisi 8. Diterjemahkan oleh A. Jaka Wasana dan Kir Iranoko, Jakarta: Erlangga.

Yang, Ya-Wan, DeWayne L. Searcy, dan Kay W. Tatum, 2006, "The Role of Corporate Governance on Long Term Financial Performance and Market Valuation of R\&D Invesment in the Biotechnology Industry".

http://finance.yahoo.com/

http://www.cic-fcgi.org/news/files/Pedoman_GCG_060906.pdf

www.bi.go.id

www.idx.co.id

www.swa.co.id 